\title{
Adaptation to climate change: does spatial planning help? Swarm planning does!
}

\author{
R. Roggema \\ Climate Adaptation and Regional Planning, \\ Province of Groningen, The Netherlands \\ Delft University of Technology, Faculty of Architecture, \\ Climate Design and Sustainability, The Netherlands \\ Wageningen University and Research Centre, \\ Earth Systems Science, The Netherlands
}

\begin{abstract}
Planning for the longer term is not yet common in spatial planning practice and as climate change appears as a long-term problem, the adaptation of society to climate change is not really facilitated by current spatial planning, used as it is to fix the future, think in closed terms about the future and designing blueprint plans for the future. In the so-called hotspot climate proof Groningen, the content of climate proofing a region is investigated and this resulted in the development of a new planning paradigm which enables planning for the longer term: swarm planning. In this paradigm the region is seen as an adaptive complex system, which can be planned according the rules of complexity. It is more effective to intervene spatially at a strategic location and let the process evolve from that moment on instead of blueprinting a future, which will be different than expected. The case of Groningen and the swarm planning principles illustrate that the regional spatial and climate proofing quality can be improved.
\end{abstract}

Keywords: climate change, swarm planning, regional planning, adaptation, long-term, Groningen, complexity.

\section{Long-term planning}

The current practice of spatial planning is oriented on the short-term. Short is here defined as a period less than ten years, because the working effect of spatial plans is ten years and for a ten-year period the future can be more or less 
'predicted'. For instance, the growth or decline of the population or the amount of households of an area can be calculated pretty exact if the period looked at counts ten years. Other developments are far more difficult to estimate. The expectations about the possible changes in climate are projected on periods of 50 to 100 years. And if the climate models of 2001 [1] and 2006 [2] are compared [3] the differences are relatively large.

Moreover, if we know that the "best" is yet to come, namely unexpected and sudden shocks in the melting of land ice, the effects of climate change are even more difficult to guess. Because of these uncertainties and expectations in the longer term, spatial planning has great difficulties to implement or integrate these topics in daily practice [4]. The gap between these kinds of long-term developments, the existing planning practice, which focuses on a ten-year period and the political timeframe, which is even shorter (figure 1), causes a lack of action. And this action is required due to the fact that the upcoming changes in climate are already caused by the $\mathrm{CO}_{2}$ emissions from the past. The changes in the far future are caused today and need to be anticipated further on. Above this, climate changes at a continuously faster pace. It seems that predictions on expected changes are reached sooner and that the climate changes are going faster and the changes are stronger than expected [5].

Spatial planning is, due to its limited focus of ten years, not capable of providing an appropriate answer to this problem. Stopping planning for longer terms could be one option to solve this, but trying to find a new way of planning could be another.

\section{Hotspot climate proof Groningen}

The scientific program Climate changes Spatial Planning (CcSP) [6] programs the research in the Netherlands on the effects of climate change for the Dutch situation and explores ways to adapt to these changes. The usage of scientific research in practice is organised through the introduction of climate proof hotspots. A hotspot is a location that offers Internet access; it is a place for people to connect. A hotspot is also a region of high activity within a larger area of low activity [7]. CcSP combine the two meanings and developed the concept of hotspots as being areas where science and practice connect and where transdisciplinary research is carried out in 'melting pot' conditions: with many people and over a relatively short period. In 2006 the Hotspot definition study was carried out to identify, describe and evaluate possible hotspots. A hotspot was defined as a pilot project in a region in which spatial planning and climate change play an important role and where conflicts of interest are found between these and other factors [8]. CcSP intended to start hotspots in order to apply and integrate knowledge in the field. In the so-called 'hotspot climate proof Groningen' the content of a climate proof region is researched [9]. The province of Groningen is the northernmost province in the Netherlands, bordering the Wadden Sea and prone to different effects of climate change: the rising sea level increases the risk at floods, more and heavier precipitation increasing the risk of inundations in winter, dry summers leading to long periods of drought, leading to 


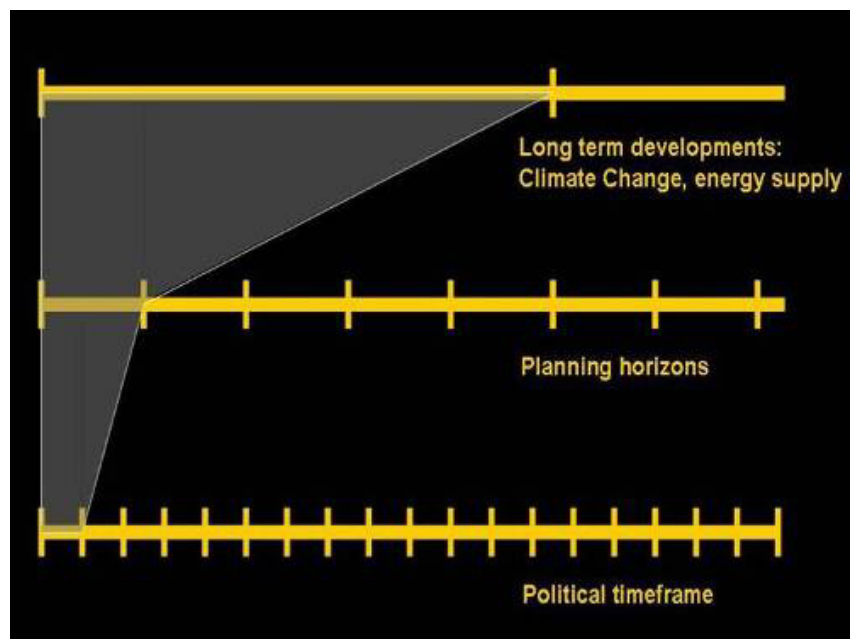

Figure 1: Gap between long-term developments and current political and planning practices [4].

uncertainties about the availability of fresh water and higher temperatures and more extremes making nature more vulnerable. In several expert sessions the adaptive solutions for Groningen Province were designed. For the coastal defence a combinatory of solutions was proposed, which in combination with each other provide a better safety level than a single solution. The combination of a strong dike with a flexible front and land zone and a second, lower, dike seems to be very effective [10]. In order to make the vulnerable nature climate proof, existing valuable areas need to be enlarged and better connected (figure 2), especially the robust connections that are capable of providing the extensions of spaces and the routes between the nature areas of origin and the ones species leave due to climate change [11].

Fresh water supply will be an increasing problem in the future because of the probability of very dry summer periods and the fact that currently surpluses of rainwater are pumped as rapidly as possible towards the sea. There it becomes useless immediately. Solutions for this problem (figure 2) include the creation of
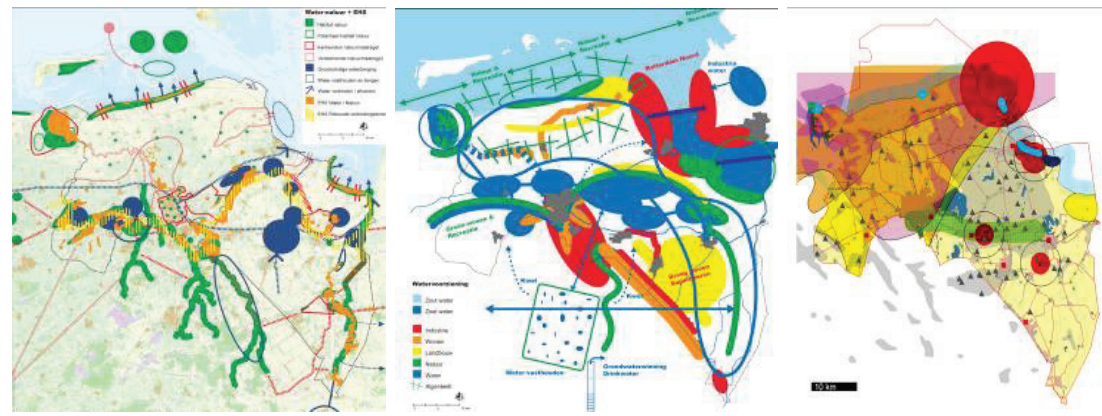

Figure 2: $\quad$ Climate proof nature [11], water supply [12] and energy [13]. 
fresh water-reservoirs in rivers, sea arms or the lowest parts of the landscape, reuse and cascading of water qualities and innovative production of fresh water in algae plantations or during the drying processes of agricultural products [12]. The results related to energy focus on the knowledge that a large amount of energy can be sustainably supplied locally. Due to the dominance of oil and gas extractors the local potentials are underestimated. Once the energy potentials are mapped at a regional level [14], it becomes clear which potentials for sustainable supply are available in the region (figure 2).

In order to give the future adaptation options a background of a sustainable equilibrium the backtracking method is used [15]. The method can be very well used if a long-term and integral vision must be developed and is very suitable for defining a climate proof future. If the backtracking method is used in Groningen province the track back to a sustainable equilibrium contains the following key elements: a continuous rise of the ground level, marine clay on peat and a tidal salt marsh in the coastal zone, little brooks and sponges storing water on the plateau, bigger rivers penetrating the coastline and people living on higher grounds between rivers and brooks.

When these characteristics are combined with an accelerated climate change with sea level rises of five metres or more in 2300 [16] and they are used in a planning process, three spatial models are developed (figure 3) [17]. The three backtracked integral and climate proof future visions can be seen as the background of future possibilities against which future adaptation policy must be defined. If policies fit in the different future models the policy can be called robust: the policy is able to withstand future changes and uncertainties for the largest part. Talking about climate change and adaptation policies, these policies are robust when they fit in the backtracked future visions.
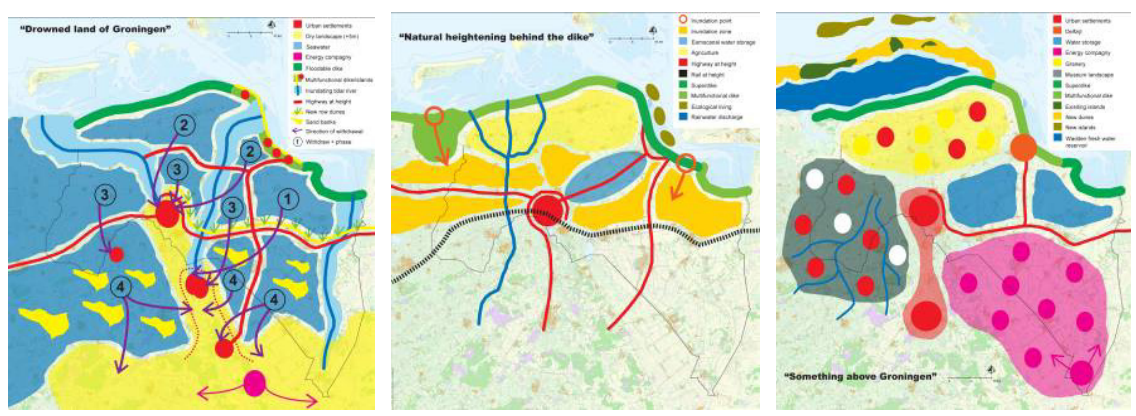

Figure 3: Backtracking the future of Groningen: drowned land of Groningen, natural heightening behind the dike and something above Groningen [17].

\section{Framework and definition for a climate proof region}

In this chapter a framework for a climate proof region will be developed. In order to do so a number of concepts related to dealing with an uncertain future are explored. Because most of today's issues turn out to belong to the domain of complexity [19], several concepts related to complex adaptive systems are 
defined and researched on their applicability for spatial planning [18]. VROM [20] states that climate proofing requires the following characteristics: it is not vulnerable, resilient, robust and contains a large adaptive capacity. A broader definition of a climate proof region might be derived from the idea to increase the overall fitness [21]. Homan uses this concept for organisations, but the idea can be used for a region also. The idea behind this is that if the overall fitness of a region increases the region is better capable to anticipate or respond to climate change. The overall fitness increases if the vulnerability of the region is lower (and the resilience and robustness higher), the adaptive capacity is higher (flexibility, diversity and local ideas), the region is better prepared for the unexpected (self-organisation, self healing and emergence) and the region is easy adjustable (agility, coexistence, co-evolution, large group of elements is available). If these concepts are screened on their spatial applicability [18] and are combined the following spatial criteria for a climate proof region arise:

Areas for natural resources: The areas where water and energy resources as well as basic food production and nature refuges takes place, even if future changes are taken into account, need to be defined.

Networks strong, safe, flexible and overlapping: the water, energy, traffic and communications networks are strong, safe and flexible. The network of the natural system (water and nature) as well as that of infrastructure (traffic, communications, energy need to reach a climate proof state and in order to reach that state the interactions between networks and functions need to be triggered.

Safe living: risk areas need to be defined and a protection system needs to be developed, in which dikes, broad dikes and flexible dike zones play a role and in which is taken care of a back-up system in order to maintain the water system, energy network and villages to function.

Mix functions and provide many different elements to be apparent: forests, meadows, villages, water, urban settlements, arable land, industrial settlements, infrastructure, roads, waterways, energy plants and farms.

Landscape mosaic: create spatial and functional differences in the landscape to attract talented individuals with a mix of landscape elements. Provide a landscape with intense networks, functional combinations of overlapping structures and nodes of intensity and complexity, where people and spaces can come together and meet and that are designed as strong public spaces. Provide and define the collective memory of the landscape and safeguard historic landmarks. Create small and separable entities of communities with their own water, food and energy supply.

City differences: create spatial and functional differences in the landscape to attract talented individuals with a mix of buildings. Provide a city with intense networks, functional combinations of overlapping structures and nodes of intensity and complexity, where people and spaces can come together and meet and that are designed as strong public spaces. Provide and define the collective memory of the landscape, give living areas identity and safeguard historic landmarks.

Border: Define a clear border within which interactions take place but look also beyond the border of the region for the context. 
Open influence: Define areas where open influence is from external factors

People: create a preparedness organisation of people who are able to solve and not to 'problemise' and which can take care of communication and information to the region in times of transition.

Table 1: Three backtracking visions compared with the spatial criteria for a climate proof region.

\begin{tabular}{|l|l|l|l|}
\hline & Drowned land & $\begin{array}{l}\text { Natural } \\
\text { heightening }\end{array}$ & Something above \\
\hline $\begin{array}{l}\text { Areas for natural } \\
\text { resources }\end{array}$ & No, partly & Yes & Yes \\
\hline $\begin{array}{l}\text { Networks, strong, } \\
\text { safe, flexible and } \\
\text { overlapping }\end{array}$ & Yes & Yes & No \\
\hline Safe living & Yes & Yes & Yes \\
\hline Mix functions & Could be more & No & No \\
\hline Landscape mosaic & Yes & No & $\begin{array}{l}\text { Depends on the } \\
\text { detail }\end{array}$ \\
\hline City differences & Possible & Possible & Possible \\
\hline Border & No & No & No \\
\hline Open influence & Yes & Yes, controlled & Yes \\
\hline People & Possible & Possible & Possible \\
\hline
\end{tabular}

As table 1 illustrates, several improvements of the visions are possible, especially if the design is carried out on a more detailed level, the exact design for landscape mosaic, combination of networks and differentiation at city level need more attention. The same counts for the involvement and organisation of people.

However, the concepts that are defined and combined are leading to a definition of a climate proof region: A region that has a large adaptive capacity (flexibility, diversity and local ideas) and a low vulnerability, caused by a high resilience and robustness, it is easy adjustable (agile, coexisting patterns and coevolution) and prepared for the unexpected (self-organised, emergent and selfhealing). The region has a high overall fitness, which eases the region in anticipating on and responding to climate change.

\section{Tipping points}

The tipping point is that magic moment when an idea, trend or social behaviour crosses a threshold, tips, and spreads like wildfire. The possibility of sudden change is at the centre of the idea of the tipping point. Big changes occur as a result of small events. The situation is similar to the phenomenon of an epidemic. Epidemics follow three rules [22]: The law of the few, the stickiness factor and the power of context. These rules can be applied to planning and design.

First of all, the law of the few tells us that a successful design will originate from a small group of individuals. The design is not what the common people 
expect. To change things or if the environment changes, the design needs to be away-from-the average [23, 24]. Secondly, the stickiness factor suggests that a successful design sticks in one's heads. Once having seen the image of the design it is not forgotten. Roberts calls it a visible love mark [25]. Finally, the power of context in relation to design processes tells us that a design with huge impact provides the solution to a commonly felt problem. If a fundamental change is required, such as climate change is asking for, a widely shared context of deep trouble improves the chances of change. A sense of real urgency is required for fundamental change. A crisis will provide the energy to jump to the new situation [26]. If the existing system dissatisfies, a crisis is required to jump to the next level of complexity [27].

Lietaer and Belgin argue that we are living in a time of sharp transformation [19]. They illustrate that there is coherence between the efficiency of a system and the diversity and connectivity, which together is called the rebound capacity of the system. If efficiency increases, diversity and connectivity decreases. If a system becomes more efficient, it tends to build up a kind of self-fueling momentum (technically called "autocatalysis") that eliminates diversity as it gradually streamlines the process. Increasingly efficient systems tend to become more directed, less diverse and consequently the system becomes more brittle and fragile [19]. They argue that this is true for all systems. Efficiency and diversity are opposite attractors and natural systems tend to seek the optimum balance and not for maximum efficiency (figure 4).

Current social-political end spatial systems tend to increase their efficiency, especially under stress. And under stress or crisis the system tends to move to its efficient mode: following the streamlined pathways (figure 5(a)). This means that in a crisis-like situation the system gets increasingly off balance. The natural reaction to react to stress with more efficiency needs to be turned around and more diversity and connectivity needs to be searched for. Only then it is possible to reach optimal balance again (figure 5(b)).

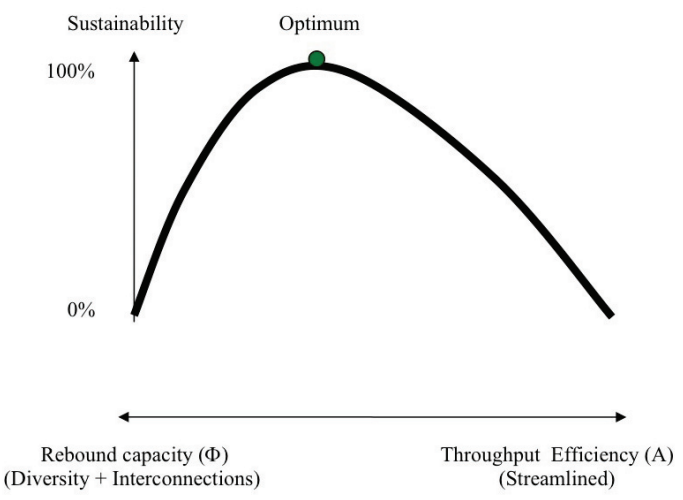

Figure 4: $\quad$ Seeking the optimum balance between efficiency and diversity [19]. 


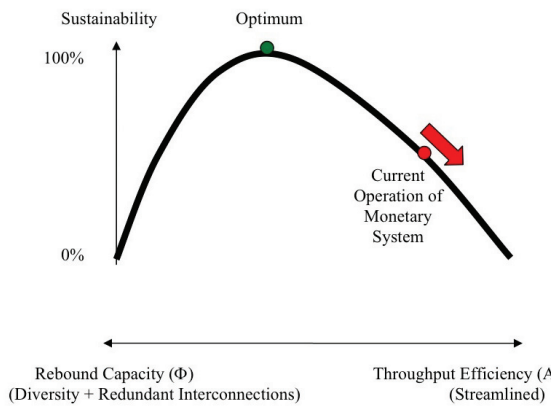

(a)

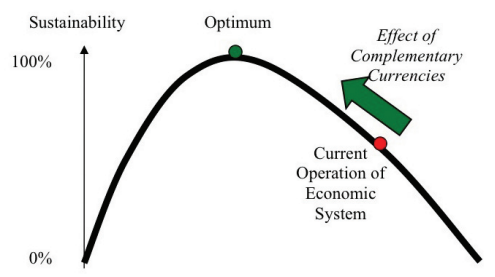

Throughput Efficiency (A) (Streamlined)

(b)

Figure 5: $\quad$ Search for optimal balance delivers the highest sustainability [19].

\section{Swarm planning principles}

Swarm planning [28] is the term invented for this new approach of planning complex adaptive systems and not defined yet. The swarm is the combinatory of networks and functions that are described in chapter 3 . In a planning process this combinatory can be put on a map of the region. This is a called swarm, because all elements together form the region and they will always do, but the swarm can change its shape under influence of an intervention. This intervention, the tipping point, enhances the swarm to change its shape. The spatial intervention enhances the combinatory of all elements to change from the existing situation towards a climate proof region. What needs to be done in a planning process? In other words, what are the swarm planning principles? The Basis (Inventory): enough conditioning mass and power; a combinatory of elements; define a spatial ambition and process/transition, which leads to an increased climate proof region. What is the optimal balance of the system and is the system getting out of balance?

1. The Place (Analysis): The choice for the right intervention. At the nodes in the network the most effective measures can be taken. From there they will influence the rest of the system and can the robustness and flexibility/dynamic of the system be enhanced at the same time;

2. The Moment (Intervention): Creation of a crisis in order to reach a tipping point. Measures, e.g. a spatial intervention, which push the system towards a threshold, enhancing tipping points to emerge;

3. The Time (Realisation): let the process emerge and the system evolve. Functions will change, land use changes, human activities change, in a stable context of unchanged spatial elements.

\section{Swarm planning: the Eemsdelta-example}

The Eemsdelta-region is located in the north-easternmost part of the Netherlands. It can be characterised as a valuable cultural landscape where old so-called wierden, artificial hills to keep living above sea level, can be found. The largest urban activities are concentrated in the city of Delfzijl, with a harbour and 
industrial settlement and the Eems harbour, a large and modern harbour at the northern shore. Typical feature of the landscape is that the more inland you go the lower the landscape is. This leads in a huge risk for the entire region: if the dike breeches near Delfzijl the major gas reserves and the regional capital will be flooded within 36 hours. If this region is taken as an example for swarm planning new planning concepts arise. Firstly, the natural system is made clear. In the Eemsdelta region much depends on the altitude in combination with the water system. If this system is analysed, the lowest parts become immediately visible: the long east west oriented depression in the landscape, which causes a probable dangerous situation in case of a flood. The second step in swarm planning is to find the node that is most vulnerable or intense. At one certain point all networks and local systems seem to come together. In the case of the Eemsdelta region this point is the dike just north of Delfzijl. A breech here causes a flood the major city in the region and parts of the gas fields will drown. Here we can think of embracing a tipping point (the third step in swarm planning) by letting the seawater flow over the dike if a storm surge boosts the water over the top of the dike. As time goes by, due to a rising sea level, more and more water will overtop the dike and more parts of the region will have to deal with wet circumstances. The time perspective depends on the pace of sea level rise, but it can be estimated that the final image (table 2) is reached by the end of the century, when sea level has probably risen 1.3 metre. If the government subsequently defines this part of the area as a zone of open influence and allows people to build their houses in the area, knowing about these wet surrounding a process of inhabiting and adapting to the changing circumstances will evolve, which is step four of the swarm planning process. People start probably building floodable houses or choose their living place at slightly higher parts in the landscape. Beside that they will adapt to changes over time, when more and more water shall be entering their living environment. How this occupation pattern exactly will evolve is difficult to predict, but in any situation the

Table 2: Climate proof criteria for the swarm planning-proposal for Eemsdelta.

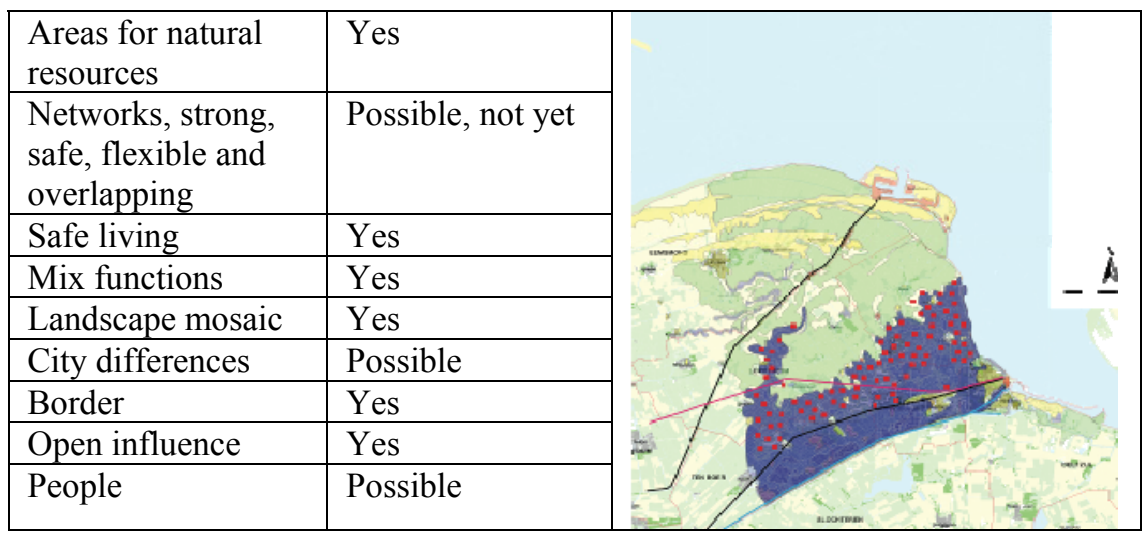


landscape and its inhabitants are adapted to the influence of climate change (of which only sea level rise is taken into account).

This example illustrates that it is possible to use an alternative planning approach in order to make use of the characteristics of a region, which is seen as a complex adaptive system. It illustrates also that adaptation to climate change can be realised, at least for the effects of sea level rise. The example swarm planning in Eemsdelta illustrates that the regional spatial system can be adapted to climate change and focus on the long-term at the same time. Table 2 shows that to a large extent the swarm planning proposal for Eemsdelta can be called climate proof. An extensive network analysis can help to improve the climate proof quality and also the differences on a city level can be explored more intensively, although a whole new living area is added to the region.

\section{Discussion}

A climate proof region is not something to develop overnight. Because of the long-term character of climate change itself it requires new and innovative processes and planning tools. So far, not many studies are conducted about the way a wicked long-term problem can be integrated in the spatial planning processes. The results presented in this paper are only the first steps towards a planning approach that meets the needs of such a problem. However, the results show that it is possible to resolve good results if the contours of swarm planning are used. The Eemsdelta example illustrates that those elements can be found, which are the core elements for a climate proof future of a region. And the example shows also that these elements are suitable to include in a spatial structure vision or zoning plan. A comparison with a regular plan for the same area could identify if swarm planning indices better results than regular planning. Moreover, if beforehand could be estimated if swarm planning produces better results, the best planning approach could be chosen. This, however, should be elaborated on in further research.

The weaknesses of the swarm planning-concept are two: the content of the basis can be explored furthermore and the usage of complex adaptive systems as guiding principle for regional spatial systems deserves more attention.

This paper proposes a set of criteria for the climate proof quality of a plan for a region. The criteria are mostly based in complexity theory. The assumption is made that these criteria are a measure for the overall fitness of a complex adaptive system and that a spatial region is a complex adaptive system. Moreover, the assumption is also that a region with a high overall fitness can better anticipate future and unexpected change, such as climate change implies. This reasoning sounds logical and is been underpinned by some literature, but it may require further support.

The swarm planning principles (the basis, the place, the moment and the time) seem to give a useful tool about how to organise a planning process, which aims to increase the level of climate proofing. The basic knowledge is sorted out, the interesting and most important point can be derived and a tipping point can be 
enhanced. Finally, the right conditions can be fulfilled to let the spatial order evolve by itself.

There is more between heaven and earth than climate change. However, if climate change is not tackled, the basis for life is under threat. So, the first thing that needs to be done in spatial planning is to expand the capability to look further in the future and take complex problems serious instead of making them simple and ready for a political one-liner. The second thing that needs to be secured is that climate change in spatial planning leads to beautiful images to look at, beloved environments to live in and appreciated landscapes to recreate and live in. The spatial quality needs to be of a very high level. Otherwise climate change and spatial planning end up as so much hype at the beginning of the $21^{\text {st }}$ century.

\section{References}

[1] Können, G.P. (2001); Climate scenarios for impact studies in the Netherlands, KNMI, De Bilt

[2] Van den Hurk, B., A. Klein Tank, G. Lenderink, A. van Ulden, G.J. van Oldenborgh, C. Katsman, H. van den Brink, J. Bessembinder, W. Hazeleger \& S. Drijfhout (2006). KNMI Climate Change Scenario's 2006 for the Netherlands, KNMI Scientific Report WR 2006-01. De Bilt, KNMI.

[3] www.knmi.nl/klimaatscenarios/vorig/wb21versusknmi06.php

[4] Roggema, R.E. (2008a); The use of spatial planning to increase the resilience for future turbulence in the spatial system of the Groningen region to deal with climate change; In: Proceedings 2008 UK Systems Society International Conference: 'Building Resilience: Responding to a Turbulent World', Oxford University, Oxford

[5] Tin, Dr. T. (2008); Climate change: faster, stronger, sooner, an overview of the climate science published since the UN IPCC Fourth Assessment Report; WWF European Policy office; Brussels

[6] www.klimaatvoorruimte.nl

[7] www.wikepedia.org (2009)

[8] Pater, F. de, (2006). Definitiestudie Klimaat Hotspots. BSIK Klimaat voor Ruimte programma, project A10

[9] Roggema, R.E. (2009b); Hotspot Klimaatbestendig Groningen, eindrapportage; Provincie Groningen en Klimaat voor Ruimte; Groningen

[10] Roggema, R.E. (2008b); De kust van Groningen, werkconferentie over de kustverdediging; Deelrapportage Hotspot Klimaatbestenidg Groningen; Klimaat voor Ruimte en Provincie Groningen; Groningen

[11] Roggema, R.E., Steingröver, E., Rooij, S. van en Troost, S. (2009a); Naar een klimaatbestendige natuur en water in Groningen; Deelrapportage Hotspot Klimaatbestendig Groningen; WUR-Alterra, Tauw, Provincie Groningen en Klimaat voor Ruimte; Groningen

[12] Roggema, R.E., Hoogeveen, H., Sanders J. (2009b); Probeer het eens wél zo gek te bedenken, rapportage klimaatbestendigheid van de 
watervoorziening in Groningen, expert meeting Allersmaborg; Deelrapportage Hotspot Klimaatbestendig Groningen; Waterbedrijf Groningen, Provincie Groningen en Klimaat voor Ruimte; Groningen

[13] Grinten, B. van der (2008); Drawing the combination of energy potentials on a provincial level; TU Delft; Delft

[14] Dobbelsteen, A.A.J.F. van den, Jansen, S and Timmeren, A. van (2007); Naar een energiegestuurd Omgevingsplan Groningen: ruimtelijke sturing door energiepotenties en warmtecascades; TU Delft, Provincie Groningen, Groningen

[15] Roggema R.E., Dobbelsteen A.A.J.F. van den (2009c); Climate adaptation and regional planning in Groningen province; Proceedings SASBE09, Delft

[16] Vellinga, Pier (2008); Hoogtij in de delta; inaugurele rede; 16 oktober 2008; Wageningen Universiteit; Wageningen

[17] Van 't Klooster, S., Pauw, W.P. en Roggema, R. (2009); De toekomst van Groningen achterwaarts onderzoeken, rapportage backcasting; Deelrapportage hotspot klimaatbestendig Groningen; VU, Klimaat voor Ruimte, Provincie Groningen; Groningen

[18] Roggema, R.E. (2009a); Complexity, planning theory and the definition of climate proof regions; (paper in preparation)

[19] Lietaer, B. and Belgin, S. (2008); Big Change. In: "Of human wealth: new money for a new world", Citerra Press

[20] VROM, Ministerie van, V\&W, LNV, EZ en IPO, VNG en UvW (2007); 'Maak ruimte voor klimaat! Nationale adaptatiestrategie - de beleidsnotitie'; VROM; Den Haag

[21] Homan, T. (2005); Organisatiedynamica; Sdu uitgevers, Den Haag

[22] Gladwell, M. (2000); The tipping point, Back bay books

[23] Ridderstråle, J. and Nordström, K (2004); Karaoke capitalism, Pearson education limited

[24] Roggema, R.E. (2005); 'Hansje Brinker, take your finger away'; Oxford Futures Forum; Oxford University; Oxford

[25] Roberts, K. (2006); The Lovemarks Effect, Winning the Consumer Revolution; Powerhouse Books; New York

[26] Timmermans, W. (2004); Crises and innovation in sustainable city planning; In: The sustainable city III; urban regeneration and sustainability: 3rd international conference on urban regeneration and sustainability; Siena (Italy), June 16-18, 2004. - Southampton (UK) [etc.]: WIT Press, 3rd International Conference on Urban Regeneration and Sustainability; Siena (Italy)

[27] Geldof, G. (2002); Coping with complexity in integrated watermanagement, Universiteit Twente, Tauw

[28] Jacobs, D. and Roggema, R. (2005); Swarm Planning; Term invented during searching conversation; Brainstorm June 2005, Groningen 